\title{
Zuzanna Urbanowicz
}

Uniwersytet Ekonomiczny w Poznaniu, Katedra Koniunktury Gospodarczej

e-mail: zuzanna.urbanowicz@ue.poznan.pl

\section{STABILNOŚĆ FINANSOWA \\ A STABILNOŚĆ MAKROEKONOMICZNA NA PRZYKŁADZIE POLSKIEJ GOSPODARKI \\ FINANCIAL STABILITY VS. MACROECONOMIC STABILITY ON THE EXAMPLE OF POLISH ECONOMY}

DOI: $10.15611 /$ pn.2018.529.32

JEL Classification: E44, E60, E61

Streszczenie: Celem artykułu jest analiza, na przykładzie Polski, związku między stabilnością finansową a makroekonomiczną. Opracowanie ma teoretyczno-empiryczny charakter. Najpierw omówiono definicje i metody pomiaru stabilności finansowej i makroekonomicznej. Następnie przedstawiono przedmiot, zakres czasowy badania i metodę badawczą. W ostatniej części zawarto wyniki analizy relacji między stabilnością finansową a makroekonomiczną. Analiza literatury doprowadziła do wniosku o braku jednorodności w definiowaniu oraz mierzeniu obu rodzajów stabilności. Warto podkreślić, że o ile w definiowaniu stabilności finansowej podkreśla się jej istotną rolę w kształtowaniu stabilności gospodarczej, to na poziomie definicji stabilności makroekonomicznej kwestia stabilności systemu finansowego jest często pomijana. Przeprowadzone badanie nie potwierdziło istnienia wpływu sytuacji systemu finansowego na stabilność makroekonomiczną, natomiast został potwierdzony związek odwrotny, tzn. stan koniunktury gospodarczej przekłada się na stabilność systemu finansowego.

Słowa kluczowe: stabilność finansowa, stabilność makroekonomiczna, analiza wielowymiarowa.

Summary: The aim of the article is to analyze the relationship between financial and macroeconomic stability in the Polish economy. The article has a theoretical and empirical character. In the first part the definitions and the methods of measuring the financial and macroeconomic stability are described. Then the subject, time range of the conducted research are presented, as well as the applied research method. The results of an empirical analysis of the bilateral relationship between financial and macroeconomic stability are contained at the end of the article. The conducted analysis of the literature leads to a conclusion that there is no uniformity in defining and measuring financial and macroeconomic stability. The conducted research confirms the existence of impact of the economic situation on the stability of the Polish financial system, while the reverse relationship, the impact of the situation in the financial system on the macroeconomic stability of Poland, has not been confirmed.

Keywords: financial stability, macroeconomic stability, multidimensional analysis. 


\section{Wstęp}

Problematyka stabilności finansowej jest obecna w literaturze przedmiotu od kilku dekad, jednak w następstwie współczesnego kryzysu finansowo-gospodarczego zyskała ponownie na znaczeniu. Załamanie gospodarek obnażyło słabości istniejących rozwiązań regulacyjno-nadzorczych w systemie finansowym oraz uświadomiło złożoność zagadnienia stabilności finansowej. Ponadto zainteresowanie wzbudziła na nowo relacja łącząca sytuację w systemie finansowym ze stanem koniunktury gospodarczej. Kryzys stał się przyczyną zmiany postrzegania roli systemu finansowego w kształtowaniu stabilności makroekonomicznej. Wcześniej rolę tę wyłącznie sygnalizowano, obecnie jest ona silnie akcentowana.

Celem artykułu jest analiza związku między stabilnością finansową a makroekonomiczną (i odwrotnie) na przykładzie polskiej gospodarki. Przyjęty cel i związane z nim główne obszary analizy zdeterminowały układ oraz teoretyczno-empiryczny charakter artykułu, który składa się z trzech części. W pierwszej z nich omówiono definicje pojęć stabilności finansowej oraz stabilności makroekonomicznej wraz z metodyką ich pomiaru. Następnie przedstawiono zakres przedmiotowy i czasowy przeprowadzonego badania, a także omówiono wykorzystaną metodę badawczą. Wyniki empirycznej analizy relacji łączącej stabilność finansową i makroekonomiczną w Polsce zawarto w kolejnej części artykułu. W zakończeniu pracy sformułowano najważniejsze wnioski wynikające z przeprowadzonych analiz.

\section{Stabilność finansowa i makroekonomiczna: definicja pojęć oraz metodyka pomiaru - ujęcie teoretyczne}

W dorobku literatury nie istnieje powszechnie stosowana, jednolita definicja stabilności finansowej (lub alternatywnie stabilności systemu finansowego ${ }^{1}$ ). Na przykład, A. Sławiński jest zdania, że stabilność finansowa ma miejsce, gdy nie występują zaburzenia w systemie pośrednictwa finansowego, które wpływałyby niekorzystnie na gospodarkę [Sławiński 2011, s. 51]. W podobny, aczkolwiek nieco bardziej szczegółowy sposób definiuje stabilność finansową A. Crockett, odnosząc ją do sytuacji, w której zmiany cen aktywów oraz trudności instytucji finansowych w zakresie wywiązywania się ze zobowiązań nie zakłócają działalności gospodarczej [Crockett 1997, s. 2]. J.M. Gonzáles-Páramo określa stabilność finansową jako sytuację, w której system finansowy jest w stanie przeciwstawić się wstrząsom, sprostać nierównowadze finansowej, ograniczając prawdopodobieństwo zakłóceń funkcjonowania pośrednictwa finansowego, które mogłyby zakłócić proces efektywnej alokacji oszczędności pomiędzy rentowne przedsięwzięcia inwestycyjne [Gonzáles-Páramo 2007, s. 6, za: Dudkiewicz 2016, s. 37]. Problematyka stabilności finan-

\footnotetext{
${ }^{1}$ Pojęcia stabilności finansowej i stabilności systemu finansowego są stosowane zamiennie zarówno w polsko-, jak i anglojęzycznej literaturze przedmiotu.
} 
sowej leży w kręgu zainteresowań nie tylko badaczy teoretyków, ale także banków centralnych. Europejski Bank Centralny (EBC) przyjmuje, że stabilność finansowa to stan, w którym nie dochodzi do kumulacji ryzyka systemowego. Ryzyko systemowe definiuje jako zagrożenie, że proces dostarczania potrzebnych produktów i usług finansowych przez system finansowy ulegnie zaburzeniu w takim stopniu, że może dojść do istotnego osłabienia wzrostu gospodarczego i obniżenia dobrobytu społeczeństwa $[\mathrm{EBC}]^{2}$. Przytoczone definicje stabilności finansowej stanowią podstawę do wyciągnięcia wniosku, że choć nie istnieje jednolita definicja tego pojęcia, to najczęściej definiuje się ją przez pryzmat warunków, których spełnienie ma sprzyjać funkcjonowaniu gospodarki w sposób niezakłócony. Oznacza to, że już na poziomie definiowania samego pojęcia stabilności finansowej podkreśla się jej znaczenie w kształtowaniu stabilności gospodarczej.

Stabilność makroekonomiczna jest najczęściej definiowana przez pryzmat celów polityki stabilizacji [Urbanowicz 2014, s. 250]. Ta zaś jest określana jako ogół działań zmierzających do tworzenia i utrzymania równowagi ogólnogospodarczej, tj. równowagi wewnętrznej i zewnętrznej [Barczyk, Kowalczyk 1994, s. 173]. Pojęcie równowagi wewnętrznej odnoszone jest do sytuacji, w której w ramach systemu rynkowego osiągnięto: stabilne i wysokie tempo wzrostu gospodarczego, wysoki poziom zatrudnienia oraz stabilność cen. Równowaga zewnętrzna jest natomiast utożsamiania z równowagą w kontaktach gospodarczych z zagranicą [Barczyk 2004, s. 16-17, 20] $]^{3}$. Przedstawione warunki równowagi ogólnogospodarczej tworzą tzw. czworokąt celów polityki stabilizacji [Pätzold 1991, s. 18]. Omawiana koncepcja czworokąta celów, zdaniem niektórych ekonomistów, nie wyczerpuje wszystkich obszarów gospodarki wymagających interwencji w ramach prowadzonej polityki stabilizacji, przez co bywa uzupełniana o inne cele. Na przykład J. Pätzold [1991, s. 18] zwraca uwagę, że w analizowanej koncepcji można uwzględnić sprawiedliwy podział dochodu narodowego jako kolejny cel i nazwać ją w związku z tym koncepcją pięciokąta celów. Z kolei G.W. Kołodko [1993] poszerza czworokąt celów o piąte kryterium stabilizacji - zrównoważony deficyt budżetu państwa, lub też budżet wykazujący pewną nadwyżkę dochodów nad wydatkami, która gwarantowałaby utrzymanie długu publicznego w wysokości umożliwiającej jego w miarę

${ }^{2}$ Szczegółowa analiza pojęcia stabilności finansowej zob. np. [Dudkiewicz 2016, s. 35-42; Iwanicz-Drozdowska 2014; Smaga 2014; Dobrzańska 2016, s. 21-27].

${ }^{3}$ Powszechnie przyjmuje się, że stabilny wzrost gospodarczy ma miejsce, kiedy dodatnia długookresowa tendencja ogólna produkcji dominuje nad jej wahaniami krótkookresowymi. Wysoki poziom zatrudnienia należy rozumieć jako możliwie niskie bezrobocie. Stabilność poziomu cen utożsamia się zazwyczaj z niską i stałą stopą inflacji, która zapewnia stabilną siłę nabywczą pieniądza. Równowaga zewnętrzna oznacza sytuację, w której nadwyżka lub deficyt w bilansie obrotów bieżących danej gospodarki nie wywołuje zakłóceń w jej równowadze wewnętrznej. Konkretyzacji niektórych celów polityki stabilizacji dokonuje się na etapie opracowywania programów polityki gospodarczej, dostosowanych do aktualnej i prognozowanej sytuacji ekonomicznej kraju. 
bezinflacyjne finansowanie. Swoją koncepcję G.W. Kołodko nazywa pięciokątem stabilizacji makroekonomicznej.

Jak wcześniej wspomniano, stabilność finansowa jest ściśle powiązana z osiągnięciem stabilności makroekonomicznej. Podczas gdy w długim okresie cele te są wzajemnie komplementarne, to w krótkim okresie stabilna sytuacja finansowa i gospodarcza nie zawsze ,idą w parze” [Jurek, Marszałek 2007, s. 17]. Z jednej strony stabilność finansowa jest niezbędnym warunkiem realizacji czworokąta/pięciokąta celów. Jednakże samo jej zapewnienie nie stanowi gwarancji osiągnięcia podstawowych celów polityki stabilizacji w sposób automatyczny. Utrzymanie stabilności finansowej względem stabilizacji makroekonomicznej należy zatem uznać za warunek konieczny, aczkolwiek nie wystarczający. Z drugiej strony stabilność makroekonomiczna rozumiana jako „zdrowe podstawy ogólnogospodarcze” stanowi warunek stabilności całego systemu finansowego, ponieważ w znacznym stopniu zmniejsza jego wrażliwość na szoki i ułatwia dążenie do poprawy sytuacji na rynku finansowym w razie ewentualnych zaburzeń [Kiedrowska, Marszałek 2002, s. 24]. Należy jednak zaznaczyć, że okresom stabilizacji gospodarczej towarzyszą zazwyczaj niskie nominalne stopy procentowe, które mogą zachęcać do podejmowania dodatkowego ryzyka w celu osiągania wyższych nominalnych stóp zwrotu. Prowadzi to do kumulowania się w gospodarce, w szczególności w systemie finansowym, nadmiernego ryzyka, które może się zmaterializować, gdy ogólny stan gospodarki się pogorszy. Stabilizacja makroekonomiczna jest zatem także warunkiem koniecznym, choć nie wystarczającym dla zapewnienia stabilności finansowej [Urbanowicz 2014, s. 251].

Proponowane przez różnych autorów definicje stabilności finansowej i makroekonomicznej są formułowane w sposób ogólny. Przytoczone definicje należałoby zatem postrzegać jako cechy stanu optymalnego, wyznaczające kierunki działań prowadzonych w ramach polityki nadzorczej i polityki stabilizacji. Ze względu na brak możliwości jednoznacznej interpretacji poszczególnych warunków równowagi finansowej i makroekonomicznej nie można w sposób jednoznaczny określić kryteriów oceny stabilności systemu finansowego oraz stabilności makroekonomicznej.

P. Smaga dokonał pogłębionej analizy metod pomiaru stabilności finansowej [Smaga 2014, s. 32-43]. Na podstawie przeglądu literatury przedmiotu wyróżnił on pięć podejść analitycznych: wskaźniki stabilności finansowej, zagregowane indeksy, testy warunków skrajnych, analizę sieciową i modelowanie ${ }^{4}$. Autor ten jest zdania, że nie można ocenić z całą pewnością, które podejście jest najlepsze, ponieważ żadne nie jest pozbawione wad. Uważa on, że należy wykorzystywać różne metody i porównywać otrzymane wyniki, aby uzyskać pełny obraz odporności systemu finansowego. Właściwa ocena kondycji systemu finansowego stanowi bowiem kluczowy warunek skutecznego doboru narzędzi ograniczania ryzyka systemowego [Smaga 2014, s. 29, 41].

${ }^{4}$ Szczegółową charakterystykę i ocenę każdej z metod zawiera praca [Smaga 2014, s. 32-43]. 
Stan koniunktury danej gospodarki ocenia się najczęściej na podstawie kształtowania wybranych danych makroekonomicznych lub na podstawie zagregowanych indeksów. Jedna z proponowanych w literaturze przedmiotu metod oceny stabilności makroekonomicznej została opracowana w 1990 r. w Instytucie Koniunktur i Cen Handlu Zagranicznego w Warszawie ${ }^{5}$. Jest to metoda magicznego pięciokąta stabilizacji makroekonomicznej, którą wykorzystywał w swych badaniach i spopularyzował G.W. Kołodko ${ }^{6}$. Metoda ta zakłada ocenę koniunktury gospodarczej w oparciu o pięć wskaźników gospodarczych charakteryzujących produkcję, bezrobocie, inflację, deficyt budżetowy oraz bilans płatniczy ${ }^{7}$. Z kolei w 2011 r. w Unii Europejskiej (UE), w następstwie wydarzeń współczesnego kryzysu, wprowadzono procedurę nierównowagi makroekonomicznej (Macroeconomic Imbalance Procedure - MIP) ${ }^{8}$. Procedura ta zakłada pomiar i ocenę stanu koniunktury gospodarczej krajów UE na podstawie oceny czternastu wskaźników gospodarczych, publikowanych regularnie przez Eurostat'. Sposób pomiaru tych wskaźników jest jednolity dla wszystkich krajów członkowskich, co umożliwia porównanie stabilności makroekonomicznej unijnych gospodarek i stanowi zaletę tej metody.

Podsumowując, wydaje się, że brak jednolitej, porównywalnej w skali międzynarodowej, parametryzacji pojęcia zarówno stabilności finansowej, jak i makroekonomicznej stanowi największe wyzwanie dla badaczy tej problematyki i głównych decydentów w zakresie polityki nadzorczej oraz polityki stabilizacji.

\section{Stabilność finansowa i makroekonomiczna: zakres analizy oraz metoda badaweza}

Przedmiotem przeprowadzonej analizy empirycznej jest analiza zależności między stabilnością finansową a makroekonomiczną (i odwrotnie) na przykładzie Polski w okresie I półrocze 2008 r. - II półrocze 2017 r.

Do pomiaru stanu systemu finansowego wykorzystano pochodzące z MFW wskaźniki stabilności finansowej (Financial Stability Indicators, Financial Soundness Indicators - FSI). Ich podstawową listę przedstawiono w tabeli 1.

\footnotetext{
${ }^{5} 1$ stycznia 2007 r. Instytut Koniunktur i Cen Handlu Zagranicznego został przekształcony w Instytut Badań Rynku, Konsumpcji i Koniunktur.

${ }^{6}$ Metoda ta jest rozwinięciem metody magicznego czworoboku opracowanej wcześniej przez A.W. Philipsa oraz R. Mundella.

${ }^{7}$ Szerzej na ten temat [Kołodko 1993].

${ }^{8}$ Przyczyną jej utworzenia jest zapobieganie narastaniu wewnętrznych i zewnętrznych nierównowag gospodarczych w państwach UE. Nierównowagi te narastały w wielu unijnych krajach już przed wybuchem kryzysu 2007+, przyczyniając się do zaostrzenia jego przebiegu i zachwiania stabilnością strefy euro.

${ }^{9}$ Szczegółowy opis procedury nierównowagi makroekonomicznej oraz lista 14 wskaźników znajdują się na stronie internetowej Komisji Europejskiej [KE].
} 
Tabela 1. Wskaźniki stabilności finansowej wg MFW - lista podstawowa

\begin{tabular}{|c|c|}
\hline \multicolumn{2}{|c|}{ Instytucje depozytowo-kredytowe } \\
\hline \multirow{3}{*}{ Adekwatność kapitałowa } & $\begin{array}{l}\text { 1. Kapitał regulacyjny/aktywa ważone ryzykiem } \\
\text { (współczynnik wypłacalności) }\end{array}$ \\
\hline & 2. Kapitał regulacyjny (Tier 1)/aktywa ważone ryzykiem \\
\hline & 3. Kredyty zagrożone/kapital \\
\hline \multirow{2}{*}{ Jakość aktywów } & 4. Kredyty zagrożone/kredyty brutto \\
\hline & 5. Koncentracja sektorowa kredytów/kredyty \\
\hline \multirow{4}{*}{ Dochód i rentowność } & 6. ROA \\
\hline & 7. ROE \\
\hline & 8. Marża odsetkowa/wynik brutto \\
\hline & 9. Wydatki pozaodsetkowe/wynik brutto \\
\hline \multirow{2}{*}{ Płynność } & 10. Aktywa płynne/aktywa razem \\
\hline & 11. Aktywa płynne/zobowiązania krótkoterminowe \\
\hline Wrażliwość na ryzyko walutowe & 12. Otwarte pozycje walutowe netto/kapitał \\
\hline
\end{tabular}

Źródło: [MFW1, MFW2].

Ostatecznie do badania zakwalifikowano pięć z nich (wytłuszczone w tabeli). Wybór wskaźników stabilności finansowej, ich częstotliwość oraz zakres czasowy badania były uwarunkowane dostępnością do jak najdłuższych, porównywalnych szeregów danych statystycznych, umożliwiających poprawne, nieobciążone błędem wnioskowanie.

W artykule przyjęto, że proces stabilizacji makroekonomicznej rozumiany jest jako dążenie do osiągnięcia tzw. czworokąta celów polityki stabilizacji, czyli stabilnego wzrostu gospodarczego, wysokiego zatrudnienia, stabilnego poziomu cen oraz równowagi zewnętrznej. Do pomiaru stabilności makroekonomicznej w tych czterech wymiarach wykorzystano następujące wskaźniki:

- odchylenie produktu krajowego brutto (PKB) od linii trendu, które otrzymano poprzez zastosowanie filtru Hodricka-Prescotta na szeregach indeksów dynamiki PKB w ujęciu realnym $(2010=100)$,

- zharmonizowaną stopę bezrobocia,

- zharmonizowany wskaźnik cen dóbr i usług konsumpcyjnych (Harmonised Index of Consumer Prices - HICP) wyrażony w \% (analogiczny okres roku poprzedniego $=100$ ),

- saldo obrotów bieżących w ujęciu realnym $(2010=100)^{10}$.

${ }^{10}$ Dane makroekonomiczne publikowane są z wyższą częstotliwością. Dla zachowania porównywalności z danymi finansowymi, dane półroczne otrzymano po agregacji danych miesięcznych lub kwartalnych i uśrednieniu obserwacji z próby. 
Do pomiaru stabilności finansowej i makroekonomicznej polskiej gospodarki zastosowano metodę porządkowania liniowego, którą w literaturze przedmiotu określa się również jako wielowymiarową analizę porównawczą. Polega ona na uporządkowaniu obiektów według pewnej bezpośrednio niemierzalnej cechy (stabilność finansowa oraz stabilność makroekonomiczna), ale możliwej do scharakteryzowania innymi cechami (pięć wybranych do analizy wskaźników finansowych oraz cztery przyjęte do badania wskaźniki koniunktury). Procedura porządkowania liniowego składa się z kilku następujących po sobie kroków, z których najważniejsze to: dobór zmiennych diagnostycznych, ustalenie rodzaju zmiennych (wskazanie stymulant, destymulant lub nominant), doprowadzenie ich do porównywalności, ustalenie formuły agregacji oraz rangowanie ${ }^{11}$. Dzięki zastosowaniu metody porządkowania liniowego skonstruowano syntetyczne i porównywalne indeksy stabilności finansowej $\left(I S F_{P L}\right)$ i makroekonomicznej $\left(I S M_{P L}\right)$ w Polsce.

W dalszej kolejności przeprowadzono analizę regresji, która posłużyła do zbadania zależności między stabilnością finansową $\left(I S F_{P L}\right)$ oraz stabilnością makroekonomiczną $\left(I S M_{P L}\right)$ w Polsce. W tym celu dokonano oszacowania następujących funkcji regresji:

$$
I S F_{P L}=\alpha \times I S M_{P L}+\mu+\varepsilon,
$$

gdzie: $I S F_{P L}$ - zmienna objaśniana, $I S M_{P L}$ - zmienna objaśniająca, $\alpha$ - parametr regresji, $\mu$ - wyraz wolny, $\varepsilon$ - składnik resztowy.

$$
I S M_{P L}=\alpha \times I S F_{P L}+\mu+\varepsilon
$$

gdzie: $I S M_{P L}$ - zmienna objaśniana, $I S F_{P L}$ - zmienna objaśniająca, $\alpha$ - parametr regresji, $\mu$ - wyraz wolny, $\varepsilon$ - składnik resztowy.

Do estymacji równań regresji zastosowano Klasyczną Metodę Najmniejszych Kwadratów (KMNK). Ocenę przydatności diagnostycznej oszacowanych modeli przeprowadzono poprzez analizę współczynnika determinacji $\mathrm{R}^{2}$. Statystyczną istotność poszczególnych parametrów określono za pomocą testu t-Studenta na poziomie istotności $p=0,05$ [Wooldridge 2001, s. 116-134]. Normalność rozkładu składnika resztowego testowano za pomocą testu Doornika-Hansena. Autokorelację składnika resztowego zweryfikowano na podstawie testu Breuscha-Godfreya, natomiast heteroskedastyczność składnika resztowego zbadano testem White'a [Maddala 2008, s. $244-245,292-293]^{12}$.

Na podstawie oszacowanych modeli podjęta została próba zbadania siły reakcji sytuacji w systemie finansowym na zmiany w kondycji makroekonomicznej w Polsce (i odwrotnie) poprzez wyznaczenie każdorazowo wskaźnika elastyczności [Studenmund 2014, s. 209]:

\footnotetext{
${ }^{11}$ Szczegółowe omówienie procedury porządkowania liniowego, zob. np. [Urbanowicz 2015].

${ }^{12}$ Szerzej na temat procedury weryfikacji modelu ekonometrycznego zob. np. [Kufel 2011, s. 57-67].
} 


$$
E_{I S F_{P L}}=\frac{\Delta I S F_{P L} / I S F_{P L}}{\Delta I S M_{P L} / I S M_{P L}}=\frac{\Delta I S F_{P L}}{\Delta I S M_{P L}} \times \frac{I S M_{P L}}{I_{S F_{P L}}}=\alpha \times \frac{\overline{I S M}_{P L}}{\overline{I S F}_{P L}},
$$

gdzie: $E_{I S F_{P L}}$ - wskaźnik wrażliwości systemu finansowego, $\alpha$-parametr regresji.

$$
E_{I S M_{P L}}=\frac{\Delta I S M_{P L} / I S M_{P L}}{\Delta I S F_{P L} / I S F_{P L}}=\frac{\Delta I S M_{P L}}{\Delta I S F_{P L}} \times \frac{I S F_{P L}}{I_{S M_{P L}}}=\alpha \times \frac{\overline{I S F}_{P L}}{\overline{I S M}_{P L}},
$$

gdzie: $E_{I S M_{P L}}$ - wskaźnik wrażliwości sytuacji makroekonomicznej, $\alpha$-parametr regresji.

\section{Stabilność finansowa a makroekonomiczna na przykładzie polskiej gospodarki - wyniki analizy empirycznej}

Zastosowanie procedury porządkowania liniowego doprowadziło do obliczenia indeksów stabilności finansowej i makroekonomicznej w Polsce. Ich kształtowanie się w ujęciu graficznym w badanym przedziale czasu przedstawiono na wykresach (rys. 1, rys. 2).

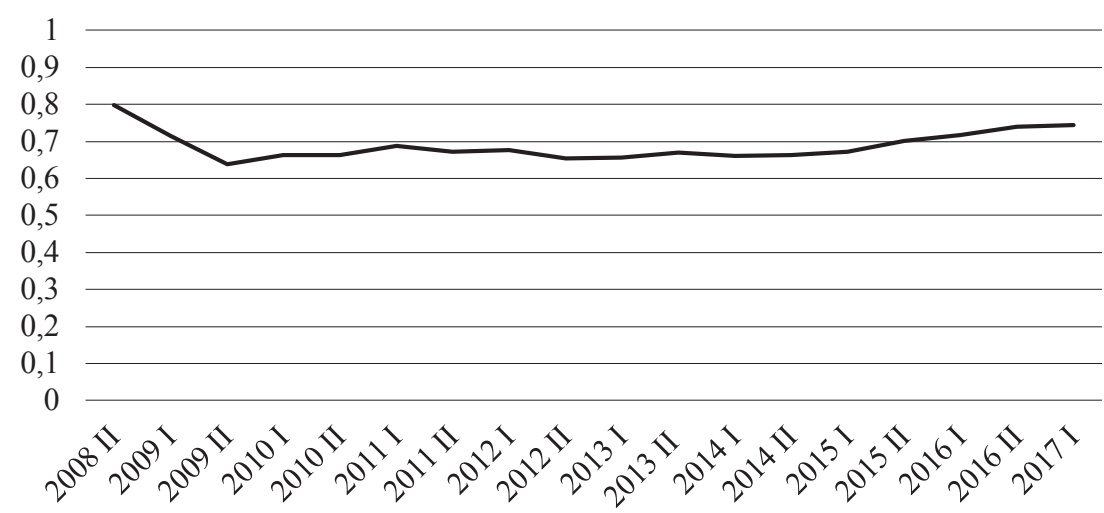

Rys. 1. Indeks stabilności finansowej w Polsce w okresie I półrocze 2008 - II półrocze 2017 Źródło: opracowanie własne.

Obliczone wskaźniki mogły przyjmować wartości z przedziału $<0,1>$ i miały charakter stymulant. Oznacza to, że wyższe wartości przekładały się na wyższy poziom stabilności (i odwrotnie) zarówno w przypadku stabilności finansowej, jak i makroekonomicznej.

Na pierwszym wykresie można zaobserwować wyraźne pogorszenie stanu polskiego systemu finansowego z początkiem drugiej połowy 2008 r. najprawdopodob- 
niej na skutek wydarzeń współczesnego kryzysu 2007+. Jednak już po roku sytuacja zaczęła się poprawiać i można uznać polski system finansowy za względnie wolny

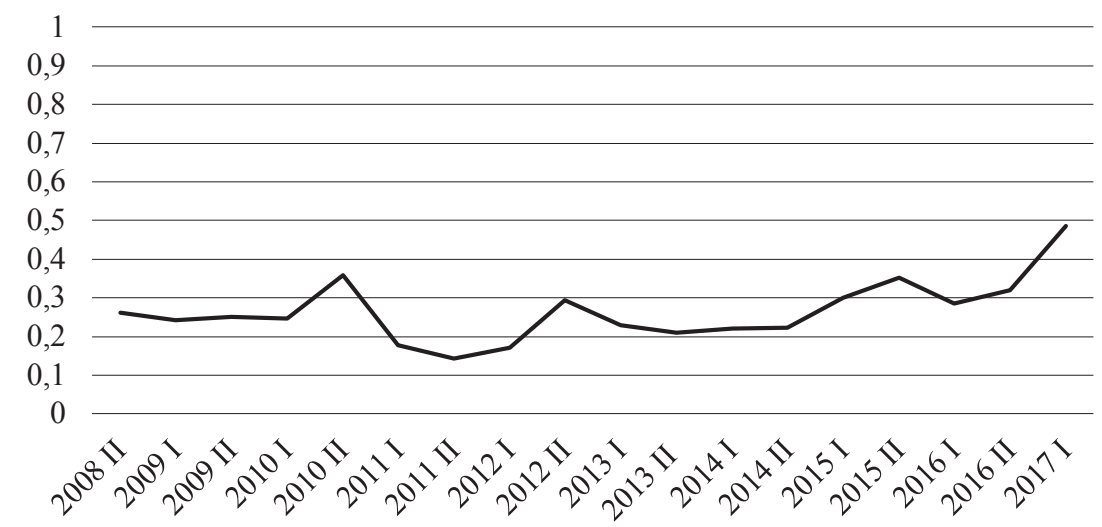

Rys. 2. Indeks stabilności makroekonomicznej w Polsce w okresie I półrocze 2008 - II półrocze 2017 Źródło: opracowanie własne.

od gwałtownych zmian przez większą część analizowanego przedziału czasu. Drugi wykres, dotyczący kształtowania wskaźnika stabilności makroekonomicznej, wskazuje na naprzemienne okresy pogorszenia i poprawy koniunktury polskiej gospodarki w analizowanym przedziale czasu.

Wyniki estymacji równań regresji (1) i (2) nie potwierdziły istnienia obustronnego związku między kondycją finansową i makroekonomiczną Polski w analizowanym okresie badawczym (tab. 2 oraz tab. 3$)^{13}$.

Tabela 2. Wyniki estymacji modelu regresji (1) dla zmiennej objaśnianej indeksu stabilności finansowej w Polsce $\left(I S F_{P L}\right)$

\begin{tabular}{|c|c|c|c|}
\hline Zmienna objaśniająca & Parametry regresji & Statystyka $t$ & $p$ \\
\hline$I S M_{P L}$ & 0,186 & 2,812 & 0,013 \\
\hline Stała regresji & 0,639 & 35,315 & $<0,00001$ \\
\hline
\end{tabular}

${ }^{13}$ Estymację modeli ekonometrycznych poprzedziły testy stacjonarności przyjętych do analizy wskaźników. Stacjonarność szeregów zbadano poprzez zastosowanie testu stacjonarności Kwiatkowskiego, Phillipsa, Schmidta i Shina [1992] przy poziomie istotności 0,05. Empiryczna wartość statystyki testu KPSS dla przyjętych do badania wskaźników stabilności makroekonomicznej i finansowej w Polsce wyniosła odpowiednio: 0,362 i 0,176, natomiast wartość krytyczna testu KPSS, przy założonym poziomie istotności, wyniosła 0,487 . Nie było zatem podstaw do odrzucenia hipotezy zerowej zakładającej stacjonarność obu szeregów. 
Źródło: opracowanie własne.

Tabela 3. Wyniki estymacji modelu regresji (2) dla zmiennej objaśnianej indeksu stabilności makroekonomicznej w Polsce $\left(I S M_{P L}\right)$

\begin{tabular}{|c|c|c|c|}
\hline Zmienna objaśniająca & Parametry regresji & Statystyka $t$ & $p$ \\
\hline$I S F_{P L}$ & 0,740 & 1,379 & 0,187 \\
\hline Stała regresji & $-0,244$ & $-0,676$ & 0,509 \\
\hline
\end{tabular}

Źródło: opracowanie własne.

Pierwszy model potwierdził istnienie związku między stabilnością finansową a makroekonomiczną. Dokładniej, model potwierdził, że stan systemu finansowego w Polsce jest zależny od jej kondycji makroekonomicznej (tab. 2). Dodatnia wartość współczynnika stojącego przy zmiennej $I S M_{P L}$ oznacza, że polepszeniu (pogorszeniu) koniunktury gospodarczej towarzyszył wzrost (spadek) wskaźnika stabilności finansowej w Polsce w danym półroczu. Oszacowany model mógł zatem stanowić podstawę do wyznaczenia wrażliwości polskiego systemu finansowego na zmianę sytuacji makroekonomicznej w Polsce. Obliczony wskaźnik elastyczności przyjął wartość 0,072. Oznacza to, że procentowy wzrost (spadek) indeksu stabilności makroekonomicznej przekładał się na wzrost (spadek) miernika stabilności finansowej w polskiej gospodarce o 0,072\%. Polski system finansowy reagował zatem stosunkowo słabo na zmiany stabilności makroekonomicznej. Siła jego reakcji była bowiem mniej niż proporcjonalna.

Finalna postać drugiego modelu regresji, oszacowanego na podstawie równania (2), nie potwierdziła istnienia zależności odwrotnej, tj. wpływu stanu systemu finansowego na kształtowanie się stabilności makroekonomicznej w polskiej gospodarce. Zmienna odzwierciedlająca stabilność finansową okazała się bowiem nieistotna w modelu (wartość $p>0,05$, zob. tab. 3). Nie było zatem podstawy do oszacowania wskaźnika wrażliwości koniunktury gospodarczej na zmiany w sytuacji systemu finansowego ${ }^{14}$.

${ }^{14}$ Komentarza wymaga niska wartość współczynnika $\mathrm{R}^{2}$, która charakteryzowała oba modele. W przeprowadzonym badaniu analizowano wyłącznie siłę i kierunek obustronnego związku między stabilnością finansową a makroekonomiczną. Niska wartość $\mathrm{R}^{2} \mathrm{w}$ takim przypadku nie budzi zastrzeżeń i oznacza, że istnieją inne zmienne, które także mogą determinować poziom stabilności systemu finansowego oraz całej gospodarki. W oszacowanych modelach nie uwzględniono dodatkowych zmiennych, które mogą wpływać na kształtowanie się stabilności finansowej oraz makroekonomicznej. W takim przypadku pożądana byłaby wyższa wartość $\mathrm{R}^{2}$. Celem badania nie była jednak analiza 
Otrzymane wyniki analizy empirycznej sugerują zatem, że polski system finansowy był w pewnej mierze wrażliwy na zmiany koniunktury gospodarczej, natomiast ona sama kształtowała się w sposób niezależny od sytuacji w polskim systemie finansowym. O ile pierwszy z wniosków nie budzi zastrzeżeń, to drugi z nich stanowi pewne zaskoczenie, ponieważ jest niezgodny z oczekiwaniami. Być może wyniki uległyby zmianie, gdyby polski system finansowy przeżywał poważne zawirowania w badanym przedziale czasu. Graficzna analiza kształtowania się wskaźnika stabilności finansowej wskazała na obecność załamania z początkiem drugiego półrocza 2008 r., jednak jego „głębokość” najprawdopodobniej nie była znacząca w sposób statystycznie istotny dla koniunktury polskiej gospodarki. Przeprowadzone badanie należałoby zatem powtórzyć za kilka lat, gdy zwiększy się długość dostępnych szeregów czasowych w bazie danych MFW.

\section{Zakończenie}

Cel artykułu stanowiła analiza związku między stabilnością finansową a makroekonomiczną (i odwrotnie) w polskiej gospodarce. Przeprowadzona na wstępie analiza literatury przedmiotu doprowadziła do wyciągnięcia wniosku o braku jednorodności w definiowaniu oraz mierzeniu stabilności finansowej i makroekonomicznej. Warto podkreślić, że o ile w definiowaniu pojęcia stabilności finansowej podkreśla się jej istotną rolę w kształtowaniu stabilności gospodarczej, to na poziomie definicji pojęcia polityki stabilizacji i stabilności makroekonomicznej kwestia stabilności systemu finansowego jest często pomijana. Dopiero wystąpienie kryzysu 2007+ spowodowało zmianę w postrzeganiu znaczenia stabilności finansowej dla stabilności makroekonomicznej. Przeprowadzone postępowanie badawcze potwierdziło istnienie statystycznie istotnej zależności między stabilnością finansową a makroekonomiczną w Polsce, tzn. sytuacja w systemie finansowym poprawia się (pogarsza się) w ślad za poprawą (pogorszeniem) koniunktury gospodarczej. Co ciekawe, drugi z oszacowanych modeli nie potwierdził istnienia statystycznie istotnego wpływu sytuacji w systemie finansowym na stabilność makroekonomiczną polskiej gospodarki. Wynik ten nie był zgodny z oczekiwaniami. Być może jego przyczynę stanowi sytuacja polskiego systemu finansowego, która w badanym okresie czasu była względnie wolna od poważniejszych zawirowań. Otrzymane w postępowaniu badawczym wyniki powinny zatem stanowić asumpt do bardziej pogłębionych badań poruszanej w pracy problematyki, które obejmowałyby dłuższy zakres czasowy oraz większy zakres przestrzenny.

\section{Literatura}

czynników wpływających na stabilność finansową oraz makroekonomiczną. W badaniu skupiono się wyłącznie na analizie bezpośredniego związku między stabilnością finansową a makroekonomiczną. 
Barczyk R., 2004, Teoria i praktyka polityki antycyklicznej, Wydawnictwo Akademii Ekonomicznej w Poznaniu, Poznań.

Barczyk R., Kowalczyk Z., 1994, Polityka stabilizacji koniunktury gospodarczej, Wydawnictwo Akademii Ekonomicznej w Poznaniu, Poznań.

Crockett A., 1997, The theory and practice of financial stability, [w:] Essays in International Finance, eds. P.B. Kenen, M.B. Riccardi, Princeton University, no. 203, s. 1-52.

Dobrzańska A., 2016, Polityka makroostrożnościowa banku centralnego, Difin, Warszawa.

Dudkiewicz B., 2016, Europejski Bank Centralny i nadzór finansowy w Unii Europejskiej a stabilność finansowa, CeDeWu, Warszawa.

Gonzáles-Páramo J.M., 2007, Progress towards a Framework for Financial Services Authority, Speech at the OECD World Forum on „Statistics, Knowledge and Policy”, 28 June.

Iwanicz-Drozdowska M., 2014, Definicje i determinanty stabilności finansowej, Bank i Kredyt, NBP, Warszawa.

Jurek M., Marszałek P., 2007, Pieniądz, polityka pieniężna i systemy kursowe. Wspótczesne teorie i rozwiazania praktyczne, Wydawnictwo Akademii Ekonomicznej w Poznaniu, Poznań.

Kiedrowska M., Marszałek P., 2002, Stabilność finansowa - pojęcie, cechy i sposoby jej zapewnienia, cz. I, Bank i Kredyt, marzec.

Kołodko G., 1993, Kwadratura pięciokata. Od załamania gospodarczego do trwatego wzrostu, Poltext, Warszawa.

Kufel T., 2011, Ekonometria. Rozwiąywanie problemów z wykorzystaniem programu GRETL, Wydawnictwo Naukowe PWN, Warszawa.

Kwiatkowski D., Phillips P.C.B., Schmidt P., Shin Y., 1992, Testing the Null Hypothesis of Stationarity against the Alternative of a Unit Root: How sure are we that economic time series have a unit root?, Journal of Econometrics, vol. 54, s. 159-178.

Maddala G.S., 2008, Ekonometria, Wydawnictwo Naukowe PWN, Warszawa.

Pätzold J., 1991, Stabilisierungspolitik. Grundlagen der nachfrage- und angebotsorientierten Wirtschaftspolitik, Paul Haupt Verlag, Bern-Stuttgart.

Sławiński A., 2011, Stabilność finansowa, [w:] Polityka pieniężna, red. A. Sławiński, C.H. Beck, Warszawa, s. 51-66.

Smaga P., 2014, Pomiar stabilności finansowej i rola banku centralnego, Bezpieczny Bank, nr 4(57), Bankowy Fundusz Gwarancyjny, Warszawa.

Studenmund A.H., 2014, Using Econometrics. A Practical Guide, 6 ed., Pearson New International Edition.

Urbanowicz Z., 2014, Stabilizacyjna rola polityki pieniężnej w warunkach unii walutowej, Ruch Prawniczy, Ekonomiczny i Socjologiczny, nr 4.

Urbanowicz Z., 2015, Stabilność makroekonomiczna nowych państw członkowskich Unii Europejskiej, [w:] Polska - 10 lat członkostwa w Unii Europejskiej, red. E. Małuszyńska, G. Mazur, I. Musiałkowska, Wydawnictwo Uniwersytetu Ekonomicznego w Poznaniu.

Wooldridge J.M., 2001, Econometric Analysis of Cross Section and Panel Data, MIT Press, Cambridge.

\section{Strony internetowe}

EBC, http://www.ecb.europa.eu/ecb/tasks/stability/html/index.pl.html (6.11.2017).

$\mathrm{KE}$, https://ec.europa.eu/info/business-economy-euro/economic-and-fiscal-policy-coordination/eu-economic-governance-monitoring-prevention-correction/macroeconomic-imbalance-procedure_en (17.11.2017).

MFW1, http://data.imf.org/regular.aspx?key=61404590 (23.04.2018).

MFW2, http://datahelp.imf.org/knowledgebase/topics/69739-concepts-and-definitions_( 23.04.2018). 